\title{
Interest Rate Risk Management of Commercial Bank under the Background of Interest Rate Liberalization*
}

\author{
Haixia $\mathrm{He}$ \\ Huanghe Science and Technology College \\ Zhengzhou, Henan, China 450006
}

\begin{abstract}
With the gradual deepening of the reform process of interest rate liberalization, commercial banks that play an important part in financial system are faced with more and more risks. The process of interest rate liberalization has important influences on commercial banks and it mainly reflects in aspects such as the decrease of interest margin of bank loans and deposits and profitability, the change of liability structure of banks and the quality of rise and reduction of preference of asset risk. The interest rate risk is the most significant risk faced by commercial banks in the process of interest rate liberalization, so Chinese banking industry needs to bear important tests in this reform. Only effective management control of interest rate risk can provide supports for the stable operation of commercial banks. This thesis is divided into four parts. The first part introduces the research background and research status of the task and explains the train of thought and structure of this article. The second part gives several tables to list some specific data of commercial banks in the aspect of interest rate risk management in recent years, summarizes and analyzes the current management situation of commercial banks for interest rate risk. The third part puts forward some unsolved problems existed in commercial banks in the process of interest rate risk management at present after overall grasp and analysis of interest rate risk. The fourth part puts forward management measures and suggestions for the existing problems.
\end{abstract}

Keywords-interest rate liberalization; interest rate risk; interest rate risk management; commercial banks

\section{INTRODUCTION}

Since the 1970s, various countries in the world have successively carried out the interest rate liberalization, including some developed countries such as America, Germany, Britain and Japan, and some emerging countries and regions such as South Korea, Taiwan and Hong Kong in China, Argentina and Chile, etc. With the rapid development of Chinese economy, after the 1990s, our country finally raises the curtain of progressive interest rate liberalization. In 1996, our country decontrolled the rate of inter bank offered credit. It has become an important symbol that we formally start the reform of interest rate liberalization. In 1999, we basically realized the interest rate liberalization of currency market and bond market. In 2004, the reform of interest rate liberalization in China achieved periodic progress, that is to say, realized the periodical target that controls the upper limit

${ }^{*}$ This article is the phased achievement of research topic of Influence of Interest Rate Liberalization on City Commercial Bank in Henan of Federation of Humanities and Social Sciences in Henan province (SKL2015-3158). of deposit interest rate and the lower limit of loan interest rate. The loan interest rate can completely and freely float above the benchmark interest rate and the deposit interest rate can completely and freely float below the benchmark interest rate. In July 20, 2013, the Central Bank decontrolled the lower limit of loan interest rate, which finally realized the interest rate liberalization. Recently, there are also new progresses. The deposit interest rate can float downward as well as upward. In November 2013, the upward floating range was 1.2 times of benchmark interest rate. So far, our country has realized the interest rate liberalization of bond market, credit market and currency market. Meanwhile, our country only controls the upper limit of deposit interest rate and decontrols the lower limit. At present, the central bank is actively promoting the deposit insurance system. It is to lay foundation and remove obstacles for the deposit interest rate liberalization. Once the deposit insurance system is launched, the upper limit of deposit interest rate will be broadened and our country will soon comprehensively realize the interest rate liberalization.

This article will adopt data in recent years to reflect the current situation of interest rate risk management of commercial banks from two aspects: the abilities of commercial banks in resisting interest rate risk and the degree of interest rate risk faced by them.

\section{CURRENT SITUATION OF INTEREST RATE RISK MANAGEMENT OF COMMERCIAL BANKS}

\section{A. Analysis on The Abilities of Commercial Banks in Resisting Interest Rate Risk}

This article will reflect the abilities of commercial banks in resisting risks through analysis of relevant data of capital adequacy ratio and asset-liability ratio.

1) Analysis on capital adequacy ratio: Capital adequacy ratio is the index to measure the degrees of risk prevention of capitals and assets of banks. The minimum standard of capital adequacy ratio of commercial banks should be no lower than eight percent. This measurement index can effectively assert creditors, enhance confidence of the masses, control the interest rate risk and maintain the security of financial system. 
TABLE I. DATA OF CAPITAL ADEQUACY RATIO OF SOME REPRESENTATIVE COMMERCIAL BANKS BETWEEN 2009 AND 2014 (UNIT: PERCENT)

\begin{tabular}{|l|l|l|l|l|l|l|}
\hline \multicolumn{1}{|c|}{ Year } & $\mathbf{2 0 0 9}$ & $\mathbf{2 0 1 0}$ & $\mathbf{2 0 1 1}$ & $\mathbf{2 0 1 2}$ & $\mathbf{2 0 1 3}$ & $\mathbf{2 0 1 4}$ \\
\hline $\begin{array}{l}\text { China } \\
\text { Construction } \\
\text { Bank }\end{array}$ & 6.88 & 6.91 & 6.51 & 11.29 & 13.57 & 13 \\
\hline Bank of China & 8.3 & 8.15 & 9.01 & 10.04 & 10.42 & 13.59 \\
\hline $\begin{array}{l}\text { Industrial and } \\
\text { Commercial } \\
\text { Bank of China }\end{array}$ & 5.76 & 5.54 & 5.52 & 7.21 & 9.89 & 14.05 \\
\hline $\begin{array}{l}\text { Pudong } \\
\text { Development } \\
\text { Bank }\end{array}$ & 11.27 & 8.54 & 8.64 & 8.03 & 8.04 & 9.27 \\
\hline $\begin{array}{l}\text { Shenzhen } \\
\text { Development } \\
\text { Bank }\end{array}$ & 10.57 & 9.49 & 6.96 & 2.30 & 3.70 & 3.71 \\
\hline Hua Xia Bank & 7.63 & 8.50 & 10.32 & 8.61 & 8.23 & 8.28 \\
\hline $\begin{array}{l}\text { China } \\
\text { Merchants Bank }\end{array}$ & 10.26 & 12.57 & 9.49 & 9.55 & 9.06 & 11.44 \\
\hline $\begin{array}{l}\text { China Minsheng } \\
\text { Banking Corp. } \\
\text { Ltd. }\end{array}$ & 10.10 & 8.22 & 8.62 & 8.59 & 8.26 & 8.12 \\
\hline
\end{tabular}

a. Data source: Almanac of China's Finance and Banking from 2009 to 2014 and annual reports on websites of banks

It can be seen from the above table that the data of capital adequacy ratio of Shenzhen Development Bank during four years from 2011 to 2014 are less than eight percent. Among joint-stock commercial banks, except for Shenzhen Development Bank, the data of capital adequacy ratio of other banks exceed eight percent. Especially for China Merchants Bank, the data have been maintained at about ten percent. Besides, the data of China Minsheng Banking Corp. Ltd and Shanghai Pudong Development Bank have been maintained at eight percent. The data of the rest three stateowned banks have successively exceed eight percent after 2013. Therefore, the overall level of capital adequacy ratio of Chinese banking industry is normal. It can only be regarded as steady development. There are very large rooms for improvement.

\section{B. Analysis on Asset-Liability Ratio}

Asset-liability ratio shows the capacity of management and control of banks for risks and the financial condition of their own. For commercial banks, it can be normal if the asset-liability ratio is between 92 percent and 95 percent. The risk is relatively high if it is above 95 percent. The condition of risk control is good if it is below 92 percent.

It can be seen from the above table that among stateowned commercial banks in China, except for Bank of China, the data have been maintained at fewer than 95 percent. The data of other commercial banks are higher than 95 percent. Among the joint-stock commercial banks, risks are relatively high in Hua Xia Bank and China Merchants Bank. The data of the several other banks are normal in one year and also relatively high in other years. Therefore, it generally shows in the analysis of asset-liability ratio that the risks in all kinds of banks are excessively high.
TABLE II. DATA OF ASSETS AND LIABILITIES OF SOME REPRESENTATIVE COMMERCIAL BANKS (UNIT: PERCENT)

\begin{tabular}{|c|c|c|c|c|c|c|c|}
\hline Bank & 2008 & 2009 & 2010 & 2011 & 2012 & 2013 & 2014 \\
\hline $\begin{array}{l}\text { China } \\
\text { Constructio } \\
\text { n Bank }\end{array}$ & $\begin{array}{l}95.4 \\
6\end{array}$ & $\begin{array}{l}96.0 \\
9\end{array}$ & $\begin{array}{l}96.5 \\
2\end{array}$ & $\begin{array}{l}94.7 \\
6\end{array}$ & $\begin{array}{l}94.9 \\
9\end{array}$ & $\begin{array}{l}93.7 \\
3\end{array}$ & $\begin{array}{l}93.6 \\
2\end{array}$ \\
\hline $\begin{array}{l}\text { Bank of } \\
\text { China }\end{array}$ & $\begin{array}{l}94.3 \\
7\end{array}$ & $\begin{array}{l}91.5 \\
9\end{array}$ & $\begin{array}{l}92.4 \\
4\end{array}$ & $\begin{array}{l}94.0 \\
7\end{array}$ & $\begin{array}{l}94.5 \\
5\end{array}$ & $\begin{array}{l}94.4 \\
6\end{array}$ & $\begin{array}{l}94.4 \\
3\end{array}$ \\
\hline $\begin{array}{l}\text { Industrial } \\
\text { and } \\
\text { Commercia } \\
1 \text { Bank of } \\
\text { China }\end{array}$ & $\begin{array}{l}95.2 \\
8\end{array}$ & $\begin{array}{l}95.5 \\
8\end{array}$ & $\begin{array}{l}96.2 \\
4\end{array}$ & $\begin{array}{l}96.7 \\
7\end{array}$ & $\begin{array}{l}97.0 \\
9\end{array}$ & $\begin{array}{l}96.0 \\
1\end{array}$ & $\begin{array}{l}96.0 \\
9\end{array}$ \\
\hline $\begin{array}{l}\text { Agricultura } \\
1 \text { Bank of } \\
\text { China }\end{array}$ & $\begin{array}{l}93.8 \\
3\end{array}$ & $\begin{array}{l}94.7 \\
3\end{array}$ & $\begin{array}{l}95.4 \\
3\end{array}$ & $\begin{array}{l}96.0 \\
5\end{array}$ & $\begin{array}{l}98.0 \\
6\end{array}$ & $\begin{array}{l}98.3 \\
3\end{array}$ & $\begin{array}{l}98.4 \\
0\end{array}$ \\
\hline $\begin{array}{l}\text { Bank of } \\
\text { Communic } \\
\text { ations }\end{array}$ & $\begin{array}{l}95.1 \\
1\end{array}$ & $\begin{array}{l}95.1 \\
0\end{array}$ & $\begin{array}{l}95.7 \\
5\end{array}$ & $\begin{array}{l}95.7 \\
2\end{array}$ & $\begin{array}{l}95.4 \\
4\end{array}$ & $\begin{array}{l}94.1 \\
6\end{array}$ & $\begin{array}{l}94.0 \\
2\end{array}$ \\
\hline $\begin{array}{l}\text { Pudong } \\
\text { Developme } \\
\text { nt Bank }\end{array}$ & $\begin{array}{l}94.3 \\
0\end{array}$ & $\begin{array}{l}95.9 \\
3\end{array}$ & $\begin{array}{l}97.0 \\
1\end{array}$ & $\begin{array}{l}96.7 \\
6\end{array}$ & $\begin{array}{l}97.0 \\
3\end{array}$ & $\begin{array}{l}97.2 \\
9\end{array}$ & $\begin{array}{l}97.3 \\
4\end{array}$ \\
\hline $\begin{array}{l}\text { Shenzhen } \\
\text { Developme } \\
\text { nt Bank }\end{array}$ & $\begin{array}{l}94.6 \\
7\end{array}$ & $\begin{array}{l}96.9 \\
8\end{array}$ & $\begin{array}{l}97.7 \\
3\end{array}$ & $\begin{array}{l}97.9 \\
4\end{array}$ & $\begin{array}{l}97.7 \\
1\end{array}$ & $\begin{array}{l}97.8 \\
0\end{array}$ & $\begin{array}{l}98.0 \\
2\end{array}$ \\
\hline $\begin{array}{l}\text { Hua Xia } \\
\text { Bank }\end{array}$ & $\begin{array}{l}96.4 \\
3 \\
\end{array}$ & $\begin{array}{l}97.8 \\
7 \\
\end{array}$ & $\begin{array}{l}97.9 \\
8 \\
\end{array}$ & $\begin{array}{l}96.5 \\
0 \\
\end{array}$ & $\begin{array}{l}96.8 \\
4 \\
\end{array}$ & $\begin{array}{l}97.0 \\
6 \\
\end{array}$ & $\begin{array}{l}97.1 \\
2 \\
\end{array}$ \\
\hline $\begin{array}{l}\text { China } \\
\text { Merchants } \\
\text { Bank } \\
\end{array}$ & $\begin{array}{l}98.3 \\
2\end{array}$ & $\begin{array}{l}98.1 \\
5\end{array}$ & $\begin{array}{l}95.5 \\
0\end{array}$ & $\begin{array}{l}96.3 \\
8\end{array}$ & $\begin{array}{l}96.4 \\
4\end{array}$ & $\begin{array}{l}96.6 \\
4\end{array}$ & $\begin{array}{l}96.7 \\
4\end{array}$ \\
\hline $\begin{array}{l}\text { China } \\
\text { Minsheng } \\
\text { Banking } \\
\text { Corp. Ltd } \\
\end{array}$ & $\begin{array}{l}92.6 \\
4\end{array}$ & $\begin{array}{l}96.0 \\
9\end{array}$ & $\begin{array}{l}97.5 \\
6\end{array}$ & $\begin{array}{l}97.3 \\
3\end{array}$ & $\begin{array}{l}97.1 \\
0\end{array}$ & $\begin{array}{l}97.2 \\
3\end{array}$ & $\begin{array}{l}97.3 \\
2\end{array}$ \\
\hline
\end{tabular}

\section{PROBLEMS EXISTED IN INTEREST RATE RISK \\ MANAGEMENT OF COMMERCIAL BANKS UNDER THE BACKGROUND OF INTEREST RATE LIBERALIZATION}

For commercial banks in China, after their interest rates are controlled for a long time, if our country suddenly deregulates its interest rate, it will be difficult for our country to manage the interest rate risk. Commercial banks are at the primary stage in the aspect and there are some problems existed in management methods and measures.

\section{A. Commercial Banks Lack Consciousness of Interest Rate Risk Management and Professional Management Talents}

Our country always implements control of interest rate and now the interest rate liberalization adopts gradual method. So it cannot let commercial banks attach enough importance to it and the response to the change of interest rate is also relatively slow. For commercial banks, the management authorities seriously pay no attention to the interest rate risk caused by interest rate change brought by interest rate liberalization, let alone understand relevant methods toward the interest rate risk management. Besides, commercial banks should have enough consciousness of risk management as well as professional talents of interest rate risk management. While at present, the current situation of our country is that there are few professional talents who 
have received systematic training for interest rate risk management system. It further makes commercial banks cannot well manage interest rate risk and correctly predict risks and recognize risks. The adverse effects brought by interest rate liberalization for commercial banks become greater.

\section{B. The Selection of Commercial Banks for The Model of Interest Rate Risk Management Is Remained to Be Improved}

There are many models of interest rate risk management. Each model has its specific advantages and disadvantages and applicability. Interest rate risk management needs series of models to accurately measure the interest rate risks. For foreign commercial banks, they have already finished the reform of interest rate liberalization and have adapted to the selection of various models of interest rate risk management. But for our country, the reform of interest rate liberalization starts relatively late. At present, we have not completely realized interest rate liberalization and each bank has characteristics of its own. So compared with foreign banks, there are big differences in the selection of models of interest rate risk management. The interest rate risk management of commercial banks in our country can not choose only one management method, but choose appropriate models of interest rate risk management according to condition of assets and specific business types and gradually improve and enhance models of interest rate risk management of commercial banks.

\section{The Abilities of Commercial Banks in Asset Allocation Are Remained to Be Improved.}

After the interest rate liberalization, commercial banks have abilities in controlling interest rate. They will attract deposits through the way of increasing deposit interest rate, which will bring higher interests for banks. Commercial banks adopt separate operation and there are homogeneities between different banking businesses. The source and use of capitals are comparatively simple. The adjustment of structure of assets and liabilities cannot well base on conditions of their own to choose different interest rates. At the present stage, the deposits and loans of commercial banks are the major income source. Once the deposit interest rate increases, it will change the debt structure and the structure of terms of deposit, make commercial banks cannot comprehensively operate and the scope will be reduced. It will be adverse to the expansion of business scale.

\section{The External Financial Market and Financial}

\section{Supervision Department Are Not Perfect Enough.}

The external financial markets in our country include monetary market, capital market, foreign exchange market and financial derivative market. But at present, the financial markets in our country are not perfect. There are problems such as the capital market and currency market are imperfect, the scale of foreign exchange market is small, and the financial derivative market is blank. Financial supervision systems in China include People's Bank of China, China Banking Regulatory Commission, China Securities
Regulatory Commission, and China Insurance Regulatory Commission. They are differentiated types of regulatory systems that concentrate on controlling risk management. However, under this system, it is not convenient for organizations to communicate and it is adverse to the cooperation and coordination. There are no very reasonable management methods for cross financial businesses. They cannot effectively supervise.

\section{MEASURES FOR INTEREST RATE RISK MANAGEMENT OF COMMERCIAL BANKS UNDER THE BACKGROUND OF INTEREST RATE LIBERALIZATION}

\section{A. Strengthen The Cultivation of Professional Talents of Interest Rate Risk Management}

In order to strengthen the management of interest rate risk and aim at the problem that the interest rate risk management lacks talents, commercial banks can choose several potential talents inside the bank and send them to foreign countries to learn foreign relatively mature methods and experience of interest rate risk management and make contributions to relevant management work in our country after combing back. Meanwhile, commercial banks also should accept virtuous persons and introduce foreign excellent talents and let these talents guide and train talents in our country. They can mutually guide and get mutual improvements and work along both line to do well in the management of interest rate risk in our country.

\section{B. The Optimization and Adjustment of Structure of Assets and Liabilities o Commercial Banks}

At the present stage, the major income source of commercial banks in our country is interest. Most of them operate traditional businesses, namely loans and deposits. Compared with banks in other developed countries, there are great disparities. The intermediate business of commercial banks developed in the future will show the interest and market position of commercial banks. Through reasonable guiding policies of resource allocation and risk management, it is necessary to energetically develop intermediate business of commercial banks, gradually change management problems of commercial banks and optimize structure of assets and liabilities.

\section{Establishment of Multilevel Interest Rate Risk Management Mechanism}

Commercial banks should constantly make efforts in the development of system and renewal of network information technology, comprehensively analyze and evaluate the data in some tables in banks such as balance sheet through the establishment of mechanisms in these two aspects and timely give relevant reference data, and then assume the displaying results of various data under different interest rate level, and finally put forward scientific and reasonable suggestions for the interest rate risk management of commercial banks. Besides, commercial banks can put capitals in different industries to make money, make the market can reasonably and effectively distribute resources and then disperse interest rate risks. 


\section{Improvement of External Financial Market and Financial Regulation}

1) Accelerate the construction of financial market: Aiming at problems existed in financial market such as imperfect capital currency market and small scale of foreign exchange market, our country should positively help the construction of financial market. For currency market, add transaction types, expand the scope of transaction subject, and establish perfect monetary payment and settlement system to ensure the rapid and efficient operation of the market. For stock market, enrich types of stock products, change the term structure of security and prompt the diversity of interest rate risk management of commercial banks. For financial derivative market, enrich trade category and energetically develop financial derivative market. The structure of financial market in our country should be perfected through the above several aspects.

2) Strengthen the control of financial regulators for the interest rate risk of commercial banks: The basis and procedure of interest rate decision of central bank are of vital importance. The data published by central bank needs to be more illustrative and more specific. Central bank should increase the frequency of data release, shorten time interval and make the transmission range of data become broader. Commercial banks should accurately grasp the decisions of central bank in advance to better manage interest rate risk.

Financial regulators should actively supervise the state of operation of commercial banks and actively collect relevant information of cash in banks and do well in the establishment of supervision system. Meanwhile, they should also establish relevant system for information disclosure of banks. There should be a constraint standard for the time of information disclosure. They should carefully prevent and strictly dispose unreasonable behaviors in the operating process to ensure that the information disclosure is comprehensive, true, timely and normative.

3) Give play to the function of self-regulatory organizations of commercial banks: Since the interest rate liberalization, although external financial regulation and relevant influences play great and positive roles in the interest rate risk of commercial banks, they should also have very good innovativeness and very strong abilities in risk management. At this time, banking association can manage and restrain the daily operation and transaction of banks very well, at the same time, make the business dealings and information communication between banks become more frequent. It gives full play to the function of self-regulatory organizations of commercial banks, effectively control the risk and prompt the faster and better development of banks.

\section{CONCLUSION}

With the advancement of the process of interest rate liberalization, the interest rate risks of commercial banks will gradually appear. This article chooses capital adequacy ratio and asset-liability ratio of commercial banks to analyze the abilities of commercial banks to resist the interest rate risk. The conclusion shows that the overall level of capital adequacy ratio of Chinese banking industry is general. It can only be regarded as steady development. There are very large rooms for improvement. The asset-liability ratio is relatively high generally. All kinds of banks show excessive high risks. The abilities of commercial banks to resist the interest rate risk are remained to be improved. This article teases the problems existed in interest rate risk management of commercial banks under the background of interest rate liberalization and puts forward corresponding suggestions: strengthen the cultivation of professional talents of interest rate risk management, the optimization and adjustment of structure of assets and liabilities, the construction of mechanism of multilevel interest rate risk management and the improvement of external financial market and financial regulation.

\section{REFERENCES}

[1] Hou Ruoyao. Research on Interest Rate Risk Management of Commercial Bank in China [D], Shanxi University of Finance and Economics.

[2] Chen Ying. Research on the Prevention of Interest Rate Risk of Commercial Bank in China under Interest Rate Liberalization [D], Shanxi University of Finance and Economics, 2014

[3] Chen Xijuan. Interest Rate Risk Management of Commercial Bank in China under Interest Rate Liberalization [J], China Market, 2014 (2)

[4] Li Zhaofang. Research on Profitability of Small and Medium-sized Commercial Banks in the Process of Interest Rate LiberalizationTake Ten Listed Small and Medium-sized Commercial Banks in China as Examples [J], New Finance, 2014(6)

[5] Hu Zheng. Exploration of Chinese Commercial Banks in Improving the Level of Interest Rate Risk Management under Interest Rate Liberalization [J], China Market, 2014(3)

[6] Han Chao. Influences of Interest Rate Liberalization on Commercial Banks in China [J], 2014(5)

[7] Huang Sufang. Interest Rate Risk Faced by Commercial Banks in the Process of Interest Rate Liberalization and Management Countermeasures [J], China Collective Economy, 2014(6) 